\title{
IMPLICATIONS OF COMPETITIVE NEUTRALITY FOR COMPETITION AGENCIES: A PROCESS PERSPECTIVE
}

\author{
Nicolas Petit*
}

\section{INTRODUCTION}

This paper sketches the implications of the competitive neutrality principle for competition agencies. The discussion is framed in a process perspective (I). The paper opens with a review of the core enforcement scenarios where a State-related firm is defendant (II) or complainant (III) in competition proceedings. It then addresses the situation in which the State is a third party to competition proceedings (IV). The paper in turn discusses theoretical de-biasing options for competitive neutrality-minded competition agencies (V). It goes on to reflect on the non-core advocacy missions of competition agencies (VI). To finish, the paper closes with words of warning (VII). A strict interpretation of the competitive neutrality principle in competition proceedings could limit agency discretion and divorce their work from the big economic picture.

\section{CONCEPTUAL FRAMEWORK}

A process-based view of competitive neutrality means that a State-related firm must not be unduly advantaged in proceedings that take place before the competition agency of its domestic State. ${ }^{1}$ At a stylized level, a State-related firm can occupy the position of defendant and complainant in competition proceedings. And advantages can conceptually arise at the four typical stages of competition proceedings, ie case selection, investigation, evaluation and remediation. Those advantages can stem from the design of the competition regime, ${ }^{2}$ but also from its implementation.

In this paper, we use the concept of a State-related firm to describe any firm that is closely or distantly linked to the State. This link can come from ownership, control, subsidies, entrustment, managerial connections or regulatory delegations. The concept of firm encompasses not only private corporations, but also non-profit organizations and public entities. It may also cover a single firm or a group of firms (for instance, firms to whom the State devolves self-regulation power). The scope of our analysis covers coordinated conduct, unilateral conduct and merger control.

\section{THE STATE-RELATED FIRM AS DEFENDANT}

The competitive neutrality principle commands that agencies should not observe undue procedural humility against State-related firms that are defendants in competition proceedings. This risk can theoretically occur at several levels. At case-selection stage, agencies may turn a blind eye on complaints that target State-related firms, and shelve them on prioritization grounds. At investigation stage, agencies may recline on inquiring State-related firms with standard diligence. At evaluation stage, agencies may promote high evidentiary standards when they review theories of liability and low evidentiary thresholds when they examine justifiability

\footnotetext{
* Professor, University of Liege (ULg), Liege Competition and Innovation Institute ("LCII"). Nicolas.petit@ulg.ac.be.

${ }^{1}$ We do not address the case where a competition authority unduly disadvantages a foreign firm in enforcement, though this could also violate the competitive neutrality principle.

${ }^{2}$ For instance, the legislation entitles the minister to lodge complaints before the CA.
} 
defenses. ${ }^{3}$ Lastly, at remedial stage, agencies may observe fining self-moderation or devise under-fixing remedies.

To be fair, those suspicions may be a little caricatured. But they provide a graphic framework to track elusive - and possibly inadvertent - competitive neutrality distortions when a Staterelated firm is defendant.

Take coordinated conduct. ${ }^{4}$ In recent years, suspicions of secret collusion have plagued the financial industry. At the same time, some financial players that were teetering on bankruptcy have been rescued by governments. In this context, distortions of competitive neutrality could be manifold. The competition agency could bargain a settlement with low fines for rescued financial institutions. It may resort to crisis-cartel reasoning in order to exonerate rescued financial institutions from substantive liability. Finally, the agency could grant discounts on fines, on grounds of inability to pay doctrines. In those scenarios, the distortion of competitive neutrality cuts two ways. On the one hand, non-rescued financial players are disadvantaged in the proceedings. On the other hand, market players from other industries understand that competition proceedings are skewed towards State-related defendants.

In unilateral conduct, utilities are a good case-study. Though the situation varies from one country to the other, utilities often remain owned by the State. And despite years of liberalization, some still occupy sizeable market positions. As a result, the monopoly profits of State-owned utilities may be a large purveyor of revenue for the State budget. ${ }^{5}$ With this background, a fiscal-sensible competition agency - after all, its own resources depend from the State budget - may decide to subject utilities defendants to quasi-systematic regulatory remedies instead of pressing against them the confiscatory fines usually charged on other dominant defendants. ${ }^{6}$ This approach, which is not unlawful in itself, may deviate from a strict reading of the competitive neutrality principle.

To avoid those risks, certain simple practical measures can be undertaken. Competitive neutrality-minded agencies can verify if ongoing cases with State-related defendants are processed under a conventional approach. Surely, there is no such thing as a "textbook" antitrust procedure. Yet, a good starting point for an agency may be to ponder whether it would have follow the same procedural approach, if the defendant was not a State-related firm.

\section{III.THE STATE-RELATED FIRM AS COMPLAINANT}

Under the competitive neutrality principle, competition agencies should not demonstrate undue procedural zeal, enthusiasm or pro-activity when a State-related firm is complainant. Put differently, a State-related firm who complains that it is the victim of supplier or rival conduct must not receive outright preferential treatment in competition proceedings. ${ }^{7}$

Like in the previous scenario, distortions of competitive neutrality can arise at four junctures. At case-selection stage, the complaint of the State-related firm may receive priority status. At investigation stage, agencies may cut through due process safeguards to reach a hasty resolution. At evaluation stage, evidentiary standards may be tweaked to lower the liability

\footnotetext{
${ }^{3}$ A high evidentiary standard for liability could be an effects-based approach, or the proof beyond reasonable doubt.

${ }^{4}$ Horizontal coordination of State-related firms is documented in many sectors: airlines, professional services, oil distribution, etc.

${ }^{5} \mathrm{Be}$ it because the State is a shareholder or because the State taxes corporate profits.

${ }^{6}$ All the more so if the agency knows that it cannot inflict the optimal fine.

${ }^{7}$ The discussion covers both formal and informal complaints.
} 
threshold and ramp up the justifiability burden. ${ }^{8}$ Finally, agencies may apply heightened fines and order extractive remedies if the victim is State-related.

To return to concrete examples, let us review the situation of complainants in coordinated conduct cases. In their fight against hard-core cartels, agencies may give over-priority to sectors in which State-related customers resort to public tenders, like construction, defence, machinery and equipment and business services sectors. Similarly, the evaluation of hard-core cartel cases may be unduly tainted by the fact that the victim is a State-related customer financed by the taxpayer. Although this is a one-liner in its decisions, the EU Commission nonetheless considered in Elevators that it was "noteworthy that some of the rigged projects were public tenders financed by taxes and carried out specifically with a view to receiving competitive and cost-effective bids". ${ }^{9}$ Finally, at remediation stage, the agency may treat with particular severity hard-core cartels in public procurement cases. For instance, the agency could set a harsher calculation methods for fines in public tenders or consider that the existence of a State-related customer is a source of aggravating circumstances.

An equally plausible risk of deviation of competitive neutrality exists in unilateral conduct cases. Take the health industry. In many countries, the ultimate buyer of health and hospital services is the State. This, in turn, is a plausible explainer for agencies' heavy enforcement initiatives against the practices of dominant drug and medical devices manufacturers (for instance, the EU sector inquiry in the pharmaceutical sector) including the recourse to intrusive investigative techniques (for instance, dawn raids). Similarly, agencies may have decided to fetch pharmaceutical cases in the "object" box, on the ground that the victims are State-related customers, and that this is a reliable proxy for consumer harm. Lastly, fines in pharmaceutical cases may have been incrementally aggravated on the ground that abusive conduct harmed State-related customers. In Plavix, for instance, the French competition agency insisted on the abuse's detrimental impact on State budget to justify its classification as a very grave infringement. ${ }^{10}$

Putting all points together, it would be undoubtedly controversial if the competitive neutrality principle was to prevent competition agencies to be particularly attentive to cases where Staterelated firms are victims of anticompetitive conduct. Instead, what competitive neutrality suggests is that competition agencies should pursue a balanced, heterogeneous case-mix. Otherwise, agencies risk (i) discouraging non State-related complainants to come forward; and (ii) chilling the incentives to do business of competitors, suppliers and purchasers of Staterelated firms.

\section{THE STATE AS “THIRD PARTY” TO THE COMPETITION PROCESS}

In our last scenario, the State is a third party to the proceedings that have commenced before the competition agency. We do not mean here to discuss the "insider" situation where the State - or a State-related firm - participates to the proceedings as an "interested party", 11 but the situation in which the State interferes as an "outsider" with competition proceedings. The State

\footnotetext{
${ }^{8}$ For instance, the agency could decide to assess a rule of reason-type case under a per se prohibition framework.

${ }^{9}$ See Commission Decision C (2007) 512 final of 21 February 2007 relating to a proceeding under Article 81 [EC] Case COMP/E-1/38.823 - Elevators and Escalators, $§ 658$.

${ }^{10}$ See http://www.autoritedelaconcurrence.fr/pdf/avis/13d11.pdf at $\$ 641$.

${ }^{11}$ In this situation, competitive neutrality prescribes that the agency should admit the State in proceedings under the same conditions as any other natural or legal person. Moreover, the legislation should not (i) give States statutory standing privileges such as those enjoyed by consumer associations or trade unions; or (ii) embed State organs in the procedure, be it for a consultative purpose.
} 
may have skin in the competition case possibly because a State-related firm a main actor in the proceedings. ${ }^{12}$

In this situation, the State seeks to influence the outcome of the proceedings from the outside, and with this causes the competition agency to stray from competitive neutrality. Much of this hypothesis can be illustrated with two merger control examples. First, the State attempts to thwart the takeover of a State-related firm, by subjecting the transaction to a garden-variety of conditions (employment, headquarter or investment-related). Such conditions may not be in themselves sufficient to obliterate the transaction. But they may create remedy "fatigue" with the parties at the later stage of merger scrutiny by the agencies. This, eventually, exacerbates the risks of merger prohibition, whilst competition concerns could have been solved with remedies. With this, merger proceedings are no longer competitively neutral, because they respond negatively to the externality occasioned by prior State action. ${ }^{13}$

Second, the State attempts to promote the implementation of a merger to which a State-related firm takes part. In this variant, the State plays "white-knight" when divestiture negotiations between the agency and the notifying parties are on the brink of collapse. In this scenario, the State (possibly through or a related entity) acts as a credible upfront buyer. This, in turn, facilitates the chances of merger clearance, whilst competition concerns might have been material. Again, the merger proceedings are no longer competitively neutral, because the outside influence of the State modifies their anticipated outcome.

Unlike in the previous sections where competitive neutrality was distorted from the inside by the competition agency, our merger illustrations show that competitive neutrality distortions can be created from the outside, on the occasion of competition proceedings.

\section{POSSIBLE DE-BIASING TOOLS}

One can think of three theoretical ways to eradicate competitive neutrality distortions in proceedings where a State-related firm is defendant or complainant.

\section{INSTITUTIONAL APPROACH}

The "expatriation" of the case to an agency from a distinct country is a first option. The agency on the receiving end cannot be suspect of home bias towards the State-related firm. It conducts the investigation and drafts a tentative decision. Once all the legwork is done, it sends the case back to the referring agency, which is sole able to give decisional force to the proposed solution on its territory.

On paper, this approach looks simple and elegant. In practice, it suffers from several fatal flaws. First, the receiving agency will remain dependent on the referring agency for investigation purposes. Thus, if a bias in favour of the State-related firm existed in the first place, the referring agency will drag its feet when asked to cooperate with the receiving agency. Second, this approach presupposes a degree of substantive and procedural convergence that nowhere exists in the international competition community, not even in the tightest networks of competition authorities (like the European Competition Network).

An alternative to expatriation is "judiciarization". The agency will refer the case to a judge, presumably on the ground that the judiciary is wholly independent from the executive branch

\footnotetext{
${ }^{12}$ The State may also be remotely connected to the case, but driven to gain an interest in it by rent-seeking conduct.

${ }^{13}$ The ongoing GE/Alstom proceedings may provide a good illustration of this. For more on this, see N. Petit, "State-created Barriers to Exit? The Example of the Acquisition of Alstom by General Electric", University of Liège School of Law, 2015, http://papers.ssrn.com/sol3/papers.cfm?abstract_id=2521378
} 
and less policy-driven than competition officials. In practice, the agency faced with a Staterelated defendant or complainant will advise the victim of the alleged infringement to seek relief in court.

Again, this is a radical idea that may do more harm than good. Judges do not enjoy similar inquisitorial, analytical and remedial powers as competition agencies. Hence, the benefits brought by "judiciarization" in terms of competitive neutrality may be outweighed by losses in competition enforcement efficiency. ${ }^{14}$ And nothing says that their home bias is lower than competition officials.

\section{SubSTANTIVE APPROACH}

Another possible approach to fix competitive neutrality distortions in competition proceedings is to offset the preferential procedural status of State-related firms with disadvantages in substantive law. In brief, State-related firms may be subject to stricter substantive principles.

Though this sounds again like a far-reaching idea, it is not unprecedented. In unilateral conduct cases, European Union ("EU") law subjects State-related defendants to harsher theories of liability. For instance, the Greek Lignite case-law removes the need to prove abusive conduct for the purposes of finding that a State-related firm infringes Article 102 and 106 of the Treaty on the Functioning of the EU. ${ }^{15}$ Similarly, the section of the Guidance Paper on Article 102 TFEU devoted to refusals to deal states that the incentives to innovate of a dominant operator is a moot defence when the market position of this firm "has been developed under the protection of special or exclusive rights or has been financed by state resources". ${ }^{16}$

Those radical doctrines are nevertheless idiosyncratic to the EU, and their transposition in other countries is very uncertain. They are based on a possible bias against the nation State, whose origin is deeply rooted in the political history of European integration.

\section{PROCEDURAL APPROACH}

A last option is to frame competitive neutrality as a due process requirement. In this variant, the legal framework puts competitive neutrality on a par with other rights of defence, such as the right to be heard, the right to business secrecy and the protection of confidential information, the presumption of innocence, etc. This may be done through constitutional instruments. This approach is likely the most practical and the least controversial to ensure competitively neutral proceedings.

\section{VI.ADVOCACY}

To close the analyzis, let us envision the scenario where the State causes a competitive neutrality distortion that is not amenable to antitrust procedure, short of a violation of the rules on coordinated or unilateral conduct. Such a situation may arise if the competitive neutrality distortion cannot be typified as a competition infringement, for instance in cases of State preferential entry regulation, selective subsidies, discretionary entrustments and attempts to

\footnotetext{
${ }^{14}$ Moreover, a certain degree of judiciarization already exists indirectly, when agency decisions are subject to judicial review and appeals. There may also be a degree of judiciarization in the context of follow-on actions for damages. On this, it ought to be noted in passing that courts should also observe competitive neutrality in such contexts. This implies refraining from giving preference to State-related firms applicants and defendants at all stages of damages litigation, for instance through larger disclosure orders, softer causation requirements, etc.

${ }^{15}$ See C-553/12 P, Commission v DEI, ECLI:EU:C:2014:2083.

${ }^{16}$ See Guidance Communication on the Commission's enforcement Priorities in Applying Article 82 of the EC Treaty to Abusive Exclusionary Conduct by Dominant Undertakings, OJ C 45 2009, pp 7-20, §82.
} 
game the antitrust process from the outside (1). Or it may occur with a competitive neutrality distortion that can be typified as anticompetitive conduct, but that evades enforcement by virtue of specific immunities (2). In both variants, we discuss the advocacy strategies that can be followed by competition agencies.

\section{Competitive Neutrality Distortions that Cannot be Typified as a COMPETITION INFRINGEMENT}

Imagine that a government mandates a technological standard. And assume that this decision de facto excludes some firms from the industry, whilst it entrenches the market position of others. In this setting, the agency can alert the government about the competitive neutrality distortion yielded by the measure. If, however, the competition agency does not enjoy a clear competitive neutrality mandate, ${ }^{17}$ the Government may simply turn a blind eye on agency advocacy, on the ground that this goes beyond the agency core competition competences. ${ }^{18}$

In advocacy contexts, storytelling is critical. With this in mind, agencies that seek competitive neutrality audience from government may be well inspired to attempt to buttress their narratives in classic competition reasoning. In this context, a promising avenue consists in tying competitive neutrality arguments to the classic theory of secondary-line injury discrimination that pervades the unilateral and coordinated conduct regimes of many competition jurisdictions. This theory of liability seeks to ensure a level playing field amongst competitors that buy from colluding oligopolists or from monopolists. It focuses on competitive disadvantages. And it only applies to those undue disadvantages that are inflicted to "equivalent" firms. Though Chicago antitrust has loathed discrimination theory as a deformity of antitrust law, ${ }^{19}$ this doctrine seems fully aligned with the competitive neutrality philosophy.

In clear, the agency could vindicate the point that if distortions of competitive neutrality are deemed problematic by the law when generated by the collective or unilateral monopoly power of private organizations, then government should exhibit equal concern with the competitive neutrality distortions caused by the regulatory, subsidy or entrustment power of public institutions. To some extent, the claim may be even advanced by competition agencies that competitive neutrality is normatively embedded in competition law.

\section{Competitive NeUtrality Distortions that CAN Be TyPifiEd AS A COMPETITION INFRINGEMENT, BUT THAT ARE IMMUNE FROM AGENCY INTERVENTION}

The State may also cause competitive neutrality distortions that can be typified as anticompetitive conduct, but that cannot be remedied by competition agencies because of the existence of legal immunities. Those immunities are diverse. They can be transversal. The Act of State Defense in US antitrust law or the State Compulsion Doctrine in EU competition law are cases in point. Those doctrines defuse the applicability of the competition rules when firms engage in anticompetitive conduct ordered by government. They can be categorical. In some jurisdictions, the lawmakers have crafted exoneration of competition liability for certain sectors (for instance, defense, professional services, etc.) or vis-à-vis certain types of organisations (for instance, SMEs).

As explained previously, the sole remedy to eliminate such distortions of competitive neutrality is advocacy in government. Again here, the narrative matters. If competition agencies want

\footnotetext{
${ }^{17}$ Leaving aside resource-constraints and instrumental issues (market studies, reports, etc.).

18 Worse even, in a public choice perspective, the agency may be suspected of attempting to enlarge its prerogatives.

${ }^{19}$ On efficiency grounds primarily.
} 
their voice to be heard, their best strategy is to stress that such measures violate the "spirit" of the competition rules. Beyond this, however, little can be done.

\section{SUMMATION}

With those remarks, we do not mean to argue that all public intervention that entails a distortion of competitive neutrality must be abandoned. Instead, the point is to underscore that competition agencies have a legitimate say in the policy debate over such distortions. This is because such distortions can often be rationalized as classic instances of secondary line injury discrimination or because they run riot with the "spirit" of competition regimes. Whether agencies have the resources and incentives to engage into such advocacy is a distinct issue.

\section{CONCLUSION}

This short paper has examined some concrete implications of the competitive neutrality principle for competition agencies. First, the risks that we have highlighted are not so much that agencies straightforwardly violate the competitive neutrality principle, but instead that they may deviate from it through subtle biases and routines in decision making that are difficult to track. Such deviations will be complex to combat and remedy.

Second, the process perspective that we have followed sheds light on several counter-intuitive consequences of the competitive neutrality principle. In particular, an orthodox application of the competitive neutrality principle risks eroding the margin of discretion of competition agencies, and this at all stages of the procedure.

Third, a rigid interpretation of the competitive neutrality principle in competition proceedings could potentially "disalign" competition enforcement from larger economic policy issues such as fiscal discipline, banking stability, etc. in which States, public institutions and the entire society have a say. Think, for instance, to cartel cases in the financial sector, where the threat of astronomic fines could nullify years of State support to failing banking institutions. With this, the competitive neutrality principle certainly furthers agency independence. At the same time, however, it risks precipitating the competition agency on the slippery slope of political illegitimacy. That agencies should not proactively further public interest objectives with competition law instruments is certainly a commendable approach. That they should ignore the big economic picture altogether is a less obvious implication. 